\title{
Habitat suitability of Anopheles vector species and association with human malaria in the Atlantic Forest in south-eastern Brazil
}

\author{
Gabriel Zorello Laporta', Daniel Garkauskas Ramos', \\ Milton Cezar Ribeiro², Maria Anice Mureb Sallum¹/+ \\ ${ }^{1}$ Departamento de Epidemiologia, Faculdade de Saúde Pública, Universidade de São Paulo, \\ Av. Dr. Arnaldo 715, 01246-904 São Paulo, SP, Brasil \\ ${ }^{2}$ Departamento de Ecologia, Universidade Estadual Paulista Júlio de Mesquita Neto, Rio Claro, SP, Brasil
}

\begin{abstract}
Every year, autochthonous cases of Plasmodium vivax malaria occur in low-endemicity areas of Vale do Ribeira in the south-eastern part of the Atlantic Forest, state of São Paulo, where Anopheles cruzii and Anopheles bellator are considered the primary vectors. However, other species in the subgenus Nyssorhynchus of Anopheles (e.g., Anopheles marajoara) are abundant and may participate in the dynamics of malarial transmission in that region. The objectives of the present study were to assess the spatial distribution of An. cruzii, An. bellator and An. marajoara and to associate the presence of these species with malaria cases in the municipalities of the Vale do Ribeira. Potential habitat suitability modelling was applied to determine both the spatial distribution of An. cruzii, An. bellator and An. marajoara and to establish the density of each species. Poisson regression was utilized to associate malaria cases with estimated vector densities. As a result, An. cruzii was correlated with the forested slopes of the Serra do Mar, An. bellator with the coastal plain and An. marajoara with the deforested areas. Moreover, both An. marajoara and An. cruzii were positively associated with malaria cases. Considering that An. marajoara was demonstrated to be a primary vector of human Plasmodium in the rural areas of the state of Amapá, more attention should be given to the species in the deforested areas of the Atlantic Forest, where it might be a secondary vector.
\end{abstract}

Key words: Atlantic Forest - disease vectors - spatial distribution - vivax malaria

Land use change, deforestation and agricultural expansion are human modifications of the natural environment, which have had direct effects on the exacerbation of malaria in the Amazon Basin (Castro et al. 2006, Vittor et al. 2006, Olson et al. 2010). Thousands of malaria cases occur annually in areas of active transmission in Brazil; however, a few autochthonous cases are reported in localities outside the Amazon Region. In the forested areas of the Atlantic coast, malarial transmission is low and irregular (Oliveira-Ferreira et al. 2010). Couto et al. (2010) reported that 444 cases of Plasmodium vivax-malaria occurred in the Vale do Ribeira on the south-eastern coast of the state of São Paulo (SP) between 1980-2007. Moreover, nonhuman primates (e.g., Alouatta guariba clamitans Cabrera) were found to be infected by P. vivax, Plasmodium malariae and Plasmodium falciparum (Curado et al. 2006, Duarte et al. 2008) in that region. In the forested areas of Vale do Ribeira, Anopheles (Kerteszia) cruzii Dyar and Knab and Anopheles (Kerteszia) bellator Dyar and Knab are vectors of malaria parasites (Forattini et al. 1999, Marrelli et al. 2007). In considering

Financial support: FAPESP (to MAMS, 05/53973-0), CNPq (BPP 300351/2008-9)

GZL is a recipient of a FAPESP doctorate fellowship (2008/05618-4).

+ Corresponding author:masallum@usp.br

Received 21 March 2011

Accepted 7 July 2011 that the presence of An. cruzii and An. bellator may be associated with vivax malaria transmission in the Atlantic Forest, it would be important to determine the potential spatial distribution of both vector species, mainly in under-sampled areas of the Vale do Ribeira.

Species of the subgenus Nyssorhynchus may also be involved in the dynamics of malarial transmission in areas outside the Amazon Region. Among the Nyssorhynchus species, it is worth mentioning Anopheles marajoara Galvão and Damasceno of the Anopheles albitarsis complex because this species is a primary vector of the human Plasmodium sp. in Macapá, state of Amapá, north-eastern Amazon. In that region, An. marajoara has replaced Anopheles darlingi Root as the primary vector and that event was associated with changes in the land use (Conn et al. 2002). Furthermore, species of the An. albitarsis complex may be involved in the dynamics of malarial transmission in certain areas of the Atlantic Forest in south-eastern Brazil. For example, $A n$. marajoara was the primary vector in the municipality of Iguape, Vale do Ribeira, in the 1940s (Schiavi 1945). The author pointed out that Iguape did not provide any suitable marshy habitat for the immature members of this species and also suggested that the adults emerged from the larval habitats in Ilha Comprida, which is separated from the continent by an estuarine complex (i.e., Mar Pequeno). Considering the epidemiological importance of the species, Correa et al. (1950) conducted a markrelease-recapture experiment to verify the dispersion of Anopheles albitarsis domesticus (= An. marajoara) between Ilha Comprida and Iguape and vice-versa. Marked specimens released in Iguape were found in Ilha 
Comprida, whereas specimens from Ilha Comprida were captured in Iguape. Wilkerson et al. (1995), employing randomly amplified polymorphic DNA polymerase chain reaction, confirmed the presence of An. marajoara in Ilha Comprida, whereas An. albitarsis s.s. and An. albitarsis B (i.e., Anopheles oryzalimnetes Wilkerson and Motoki) were found in the municipality of Registro, in the Vale do Ribeira (Motoki et al. 2009). An. marajoara was the only species of the An. albitarsis complex present in Ilha Comprida, which corroborates with Schiavi (1945) and Correa et al. (1950). However, the distribution of An. marajoara in other areas of the Vale do Ribeira is unknown mainly because of under-sampling as well as problematic species identification based mainly on morphological characteristics. Considering the importance of An. marajoara as a primary vector of human Plasmodium in Macapá (Conn et al. 2002), it is reasonable to assume that this species may be involved in the dynamics of human malarial transmission in areas outside the Amazon, such as in the Vale do Ribeira.

The distribution of An. marajoara may have been underestimated by Wilkerson et al. (1995) because some areas of the Vale do Ribeira possess adequate habitat and ecological conditions for the proliferation of the $A n$. albitarsis species complex. For example, Forattini et al. (1995) demonstrated that irrigated rice fields provide a suitable habitat for the immature An. albitarsis 1.s. Consequently, to establish the potential distribution of $A n$. marajoara in the Vale do Ribeira, it may be helpful to understand the spatial dynamics of human malaria in areas of low-endemicity in the Atlantic Forest.

Considering that the spatial distributions of the five primary vectors of human Plasmodium are not completely known in Africa, Ayala et al. (2009) applied predictive distribution modelling based on the presence of a species for constructing habitat suitability maps for Anopheles gambiae Giles, Anopheles funestus Giles, Anopheles arabiensis Patton, Anopheles nili (Theobald), and Anopheles moucheti Evans in Cameron. An. gam- biae and An. funestus were ecologically more tolerant, whereas An. arabiensis, An. moucheti and An. nili were more specialized. A similar approach was employed in the Malaria Atlas Project to establish the potential distributions of the dominant mosquito vector species of human Plasmodium (Hay et al. 2010, Sinka et al. 2010).

Considering that the majority of the Atlantic Forest is under-sampled for mosquito assemblages, ecologic niche modelling is a powerful tool that can both predict the potential spatial distribution of the vectors and assess the potential risk of exposure to human Plasmodium sp. circulating in that region. The objectives of the present study are: (i) to apply habitat suitability models to predict the potential spatial distribution of An. bellator, An. cruzii and An. marajoara; (ii) to associate autochthonous cases of human malaria with the potential spatial distribution of these mosquitoes in the Vale do Ribeira in south-eastern Atlantic Forest, Brazil.

\section{MATERIALS AND METHODS}

The study encompassed 23 municipalities of the Vale do Ribeira, which occupies $11,635 \mathrm{~km}^{2}$ within the Serra do Mar in south-eastern Brazil (Fig. 1). The region comprises the largest continuous preserved forest (approximately 1,100 million ha) in the Atlantic Forest biome (Ribeiro et al. 2009), with a hydrographic estuarine system that is intermixed with mosaics of human occupation, as well as a rich assemblage of mosquito species (Forattini \& Massad 1998). The climate is characterized as humid subtropical (Cfa in the Köppen classification).

Adult mosquito sampling was carried out monthly from May 1996-April 2000 in nine collection sites (Fig. 1) totaling 108 sampling units. To determine the habitat suitability for An. cruzii, An. bellator and An. marajoara, the total number of individuals of each species collected in the Shannon traps each month at each collection site was used as a single measurement. These values were further correlated to abiotic and biotic variables to assess the predictors of potential habitat suitability.

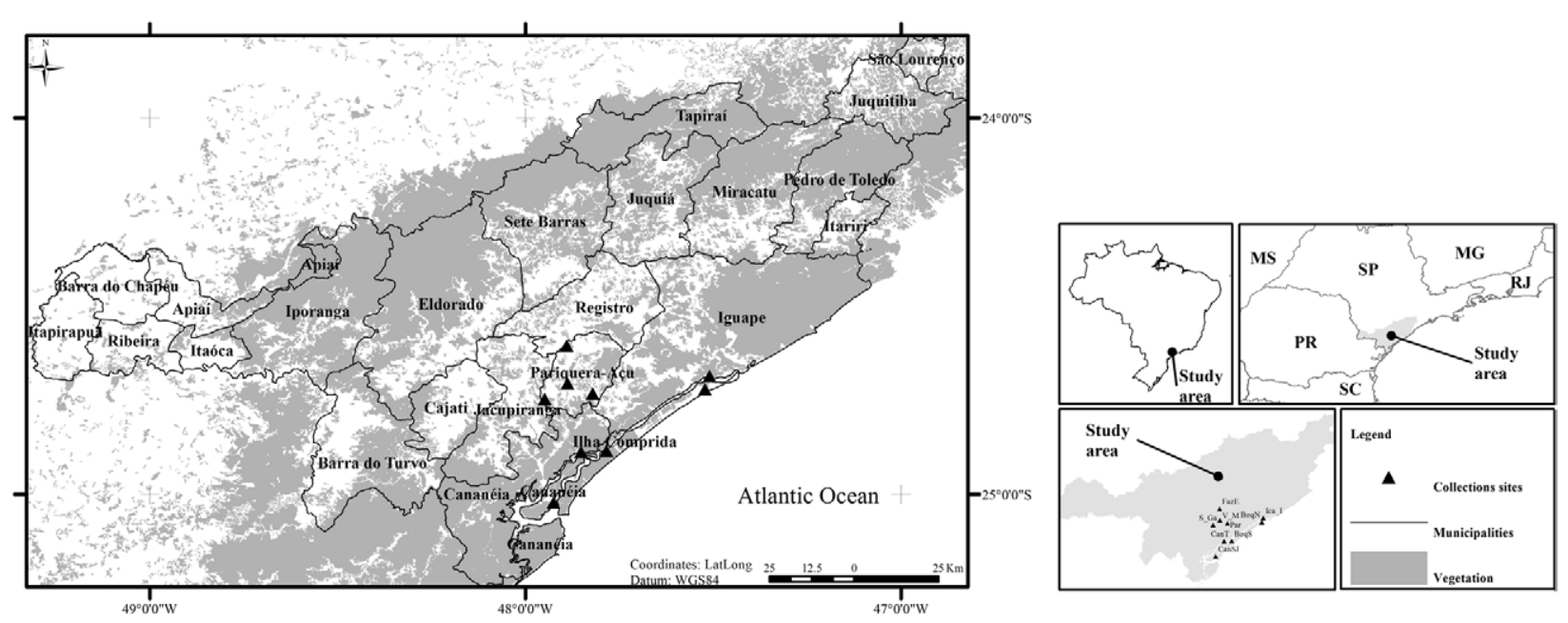

Fig. 1: twenty three municipalities of the study area Vale do Ribeira, south-eastern of the state of São Paulo, Brazil. The region is mainly covered with forest remnants in the Atlantic Forest biome. Mosquito collections were performed from nine sites. MG: state of Minas Gerais; MS: state of Mato Grosso do Sul; PR: state of Paraná; RJ: state of Rio de Janeiro; SC: state of Santa Catarina; SP: state of São Paulo. 
Terrain slope, bioclimatic variables and vegetation cover were the habitat variables that were quantified for each collection site by applying distinct routines in the GRASS 6.4 GIS software (grass.osgeo.org). These variables were assumed to represent ecologic niches because each species is potentially adapted for specific ranges of the habitat variables. The topographically variable terrain slope, derived from the Shuttle Radar Topography Mission (SRTM) 1.4 elevation map, was interpolated to a 30 -meter spatial resolution, which was assumed to be the home range of a mosquito population. Climate data from 19502000 with a 900-meter spatial resolution were acquired from the WorldClim database (worldclim.org). For the purpose of the analyses, the average maximum temperature in the warmest month was defined as Bio5, and the average annual precipitation as Biol2. Although the area encompassed in a 900-meter survey is bigger than that assumed for the mosquito population, the climate variables represented an accurate approximation for the study area. The accuracy was assessed by comparing Bio5 and Biol2 estimates to the values obtained from the local meteorological stations in the municipalities of Registro and Pariquera-Açu (ciiagro.sp.gov.br). The landscapes were characterized by the percentage of vegetation cover estimated within a 200-meter radius around each sampling site. A similar approach was used for chironomids (Roque et al. 2010), birds (Boscolo \& Metzger 2009) and carnivore mammals (Lyra-Jorge et al. 2010) in the fragmented landscapes of SP. A natural vegetation map was derived from the visual interpretation of a 30-meter spatial resolution Landsat-TM imagery (Kronka et al. 2005).

To select statistically significant abiotic and biotic variables, which can explain the potential habitat suitability of each species, a preliminary analysis was performed. In this work, the number of individuals of $A n$. bellator, An. cruzii and An. marajoara were defined as the dependent variables, whereas terrain slope, Bio5, Biol2 and vegetation cover were the independent variables. Subsequently, negative binomial regressions were run with the software R-2.9.2 (r-project.org), with the MASS package, to determine if the contribution of each variable was significant $(\mathrm{p}<0.15)$.

Using the variables selected in the aforementioned steps, the potential habitat suitability for An. cruzii, An. bellator and An. marajoara was estimated by employing the MAXENT algorithm (Phillips et al. 2006) implemented in the openModeller 1.1.0 software (openmodeller.sourceforge.net). Firstly, the MAXENT was used to estimate the coefficient value of the presence of a mosquito species as predicted by the prevailing abiotic and biotic variables. Then the coefficient values were used in 500 -iteration runs to estimate the maximum likelihood (ML) of an expected binomial distribution ( 0 , pseudoabsence; 1 , presence). The ML probability of the presence of a species was estimated for each collection site, which represented the potential habitat suitability of this species. These values varied from $0 \%$ for an unsuitable habitat to $100 \%$ for suitable habitats and were used to construct maps with a 30 -meter spatial resolution that covered the entire Vale do Ribeira region. The receiver operating characteristic (ROC) method was used to validate the potential habitat suitability maps, which were generated under stochastic modelling. The area under the ROC curve (AUC) provides a measure of accuracy (Fielding \& Bell 1997). The AUC values varied from $0-1$, where 0 meant that the model failed to establish the potential habitat suitability of a species, while a score of 1 indicated that the selected model was accurate. An AUC value of 0.9 was used as the cut-off for determining model adequacy (Metz 1986). In considering that a given species did not have a random spatial distribution because its habitat was not randomly distributed (Hanski 1994), a second validation process was performed based on the concept of a metapopulation structure (Soberón 2007). To do this validation, a Poisson distribution model was used. A species potential distribution map was considered as validated when the potential habitat suitability of a specific collection site was higher than $80 \%$. An $80 \%$ cut-off was used as a standard because it represented those localities in which the species reached the optimum habitat and thus could be involved in the transmission of Plasmodium.

The terrain slope, Bio5, Bio12, vegetation cover and potential habitat suitability of An. bellator, An. cruzii and An. marajoara data were extrapolated for the entire region of the Vale do Ribeira. The extrapolation was conducted by correlating potential habitat suitability with abiotic and biotic variables, which were aggregated for each municipality. The mean pixel values of each variable were estimated by using the spatial analyst extension of ArcMap 10 software (esri.com). The Spearman's rank test was used to estimate the correlation coefficient between the pixel mean of potential habitat suitability (dependent variable) and each abiotic and biotic variable $(\mathrm{p}<0.10)$.

Finally, an association between the prevalence of mosquito bites and malaria cases was assessed. Prevalence to mosquito bites was assumed to be positively linked to the potential habitat suitability values. Poisson regressions were applied using the numbers of autochthonous cases of malaria that were registered for each municipality from 1996-2000 as dependent variables. The number of malaria cases was obtained from Couto et al. (2010). Potential habitat suitability values aggregated per municipality were transformed into a binary variable $(0=$ absence; 1 = presence) for each species and later used as independent variables. A species was considered present in a specific locality when the value of the habitat suitability was $\geq 80 \%$, whereas a $<80 \%$ cut-off value meant absence. Cases of malaria were tested to ascertain whether they had a Poisson distribution using the Moran Global Autocorrelation test. Considering that malaria cases have a Poisson distribution, the regression coefficients were estimated using a generalized linear model to estimate the prevalence ratio (PR) of the disease associated with multiple independent variables. The variables were altered into dummy variables as follow: $\mathrm{X}_{1}=$ An. bellator (model 1); $\mathrm{X}_{2}=$ An. cruzii $\left(\right.$ model 2); $\mathrm{X}_{3}=$ An. marajoara (model 3); $\mathrm{X}_{4}=$ both An. bellator and An. cruzii (model 4); $\mathrm{X}_{5}=$ both An. bellator and An. marajoara (model 5); $\mathrm{X}_{6}=$ both An. cruzii and An. marajoara (model 6); $\mathrm{X}_{7}=$ 
An. bellator, An. cruzii and An. marajoara (model 7). The $\mathrm{PR}$ and the confidence interval (95\%) were estimated in the software R-2.9.2 with the epicalc package to identify mosquito species that were positively associated with malaria $(\mathrm{PR}>1 ; \mathrm{p}<0.05)$.

\section{RESULTS}

A total of 8,288 females of An. bellator, An. cruzii and An. marajoara were captured in Shannon traps in nine localities of the Vale do Ribeira. Collection sites, mosquito species and both abiotic and biotic variables are shown in Table I. The mean and standard deviations of the number of each type of mosquito collected per month are in the Supplementary data. The total number of mosquitoes showed a negative binomial distribution in which abiotic and biotic variables were added to estimate the coefficients of the univariate regressions. The significant coefficient indicated that the terrain slope and vegetation cover (An. cruzii), Biol2 and vegetation cover (An. bellator) and Bio5 and vegetation cover ( $A n$. marajoara) were the most explicative variables; thus they were selected for the potential habitat suitability modelling for each species (Table II).

Potential habitat suitability maps are shown in the Supplementary data for An. bellator (range: 4-88\%, AUC: 0.95), An. cruzii (range: 51-97\%, AUC: 0.91) and

TABLE I

Collection sites, mosquito species and abiotic and biotic variables in the south-eastern Atlantic Forest of Brazil

\begin{tabular}{|c|c|c|c|c|c|c|c|}
\hline Sites & $\begin{array}{c}\text { Anopheles } \\
\text { bellator }\end{array}$ & $\begin{array}{c}\text { Anopheles } \\
\text { cruzii }\end{array}$ & $\begin{array}{l}\text { Anopheles } \\
\text { marajoara }\end{array}$ & $\begin{array}{l}\text { Terrain } \\
\text { slope } \\
\left(^{\circ}\right)\end{array}$ & $\begin{array}{l}\text { Average annual } \\
\text { precipitation } \\
(\mathrm{mm})\end{array}$ & $\begin{array}{l}\text { Average maximum } \\
\text { temperature in the } \\
\text { warmest month } \\
\left({ }^{\circ} \mathrm{C}\right)\end{array}$ & $\begin{array}{l}\text { Vegetation } \\
\text { cover } \\
(\%)\end{array}$ \\
\hline BoqN & 18 & 194 & $126^{a}$ & 0 & 2,116 & 29.9 & 15 \\
\hline BoqS & $1,796^{a}$ & 509 & 21 & 1 & 2,279 & 30.5 & 64 \\
\hline CanSJ & $523^{a}$ & 454 & 4 & 9 & 2,469 & 30.6 & 27 \\
\hline CanT & 316 & $2,751^{a}$ & 0 & 13 & 2,272 & 30.2 & 77 \\
\hline FazE & 0 & 352 & 9 & 2 & 1,915 & 30.9 & 3 \\
\hline S_Ga & 11 & 611 & 0 & 4 & 2,043 & 30.5 & 81 \\
\hline Ica_I & 36 & 543 & 0 & 0 & 2,096 & 29.5 & 93 \\
\hline Par & 0 & 14 & 0 & 1 & 2,060 & 30.6 & 0 \\
\hline V_M & 0 & 0 & 0 & 0 & 2,012 & 30.8 & 0 \\
\hline
\end{tabular}

$a$ : higher mosquito frequency as expected in a Poisson distribution. These collections sites were herein considered as the source of a mosquito-specific species, i.e., a location with ecological characteristics that positively influence the population growth. These localities were the control sites utilized for the validation of potential habitat suitability modelling. Mosquito collection sites: BoqN: Ilha Comprida (North); BoqS: Ilha Comprida (South); CanSJ: Cananéia; CanT: Sítio Itapuã; FazE: Fazenda Experimental; S_Ga: Sítio Galiléia; Ica_I: Icapara; Par: Pariquera-Mirim; V_M: Vila Maria.

\section{TABLE II}

Preliminary analysis: equations of negative binomial regression models and significance of coefficient $\beta_{1}$ of the independent variable $\mathrm{X}_{1}(\mathrm{p}<0.15)$

\begin{tabular}{|c|c|c|c|c|}
\hline Species & $\begin{array}{l}\text { Terrain } \\
\text { slope } \\
\left(^{\circ}\right)\end{array}$ & $\begin{array}{l}\text { Average annual } \\
\text { precipitation } \\
(\mathrm{mm})\end{array}$ & $\begin{array}{l}\text { Average maximum } \\
\text { temperature in the } \\
\text { warmest month } \\
\left({ }^{\circ} \mathrm{C}\right)\end{array}$ & $\begin{array}{l}\text { Vegetation } \\
\text { cover } \\
(\%)\end{array}$ \\
\hline $\begin{array}{c}\text { Anopheles bellator } \\
\text { Coefficient } \beta_{1}\end{array}$ & $\begin{array}{c}5.59+0.03 \mathrm{X}_{1} \\
\mathrm{z}=0.17, \mathrm{p}<0.87^{a}\end{array}$ & 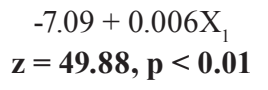 & $\begin{array}{c}-45.29+0.17 \mathrm{X}_{1} \\
\mathrm{z}=0.86, \mathrm{p}<0.40^{a}\end{array}$ & $\begin{array}{c}3.20+0.05 X_{1} \\
\mathbf{z}=\mathbf{2 . 3 7}, \mathbf{p}<\mathbf{0 . 0 2}\end{array}$ \\
\hline $\begin{array}{l}\text { Anopheles cruzii } \\
\text { Coefficient } \beta_{I}\end{array}$ & $\begin{array}{c}5.39+0.18 X_{1} \\
\mathbf{z}=\mathbf{6 9 . 4 7 ,} \mathbf{p}<\mathbf{0 . 0 1}\end{array}$ & $\begin{array}{c}-1.80+0.004 \mathrm{X}_{1} \\
\mathrm{z}=1.27, \mathrm{p}<0.21^{a}\end{array}$ & $\begin{array}{c}44.83-0.13 X_{1} \\
z=-1.01, p<0.28^{a}\end{array}$ & $\begin{array}{c}4.88+0.03 X_{1} \\
\mathbf{z}=\mathbf{0 . 0 3}, \mathbf{p}<\mathbf{0 . 0 2}\end{array}$ \\
\hline $\begin{array}{l}\text { Anopheles marajoara } \\
\text { Coefficient } \beta_{1}\end{array}$ & $\begin{array}{c}3.36-0.34 X_{1} \\
z=-1.35, p<0.18^{a}\end{array}$ & $\begin{array}{c}4.16-0.001 X_{1} \\
z=-0.10, p<0.92^{a}\end{array}$ & $\begin{array}{c}49.77-0.16 X_{1} \\
\mathbf{z}=\mathbf{- 9 . 5}, \mathbf{p}<\mathbf{0 . 0 0 1}\end{array}$ & $\begin{array}{c}3.40-0.04 X_{1} \\
\mathbf{z}=\mathbf{- 1 . 5 6}, \mathbf{p}<\mathbf{0 . 1 2}\end{array}$ \\
\hline
\end{tabular}

$a$ : this variable was not selected to potential habitat suitability modelling of the given species $(\mathrm{p}>0.15) . \mathrm{X}_{1}$. independent variable An. bellator, An. cruzii and An. marajoara. The results printed in bold represent significant outcomes under the null hypotheses $\left(B_{1}=0 ; \mathrm{p}<0.15\right)$. 
An. marajoara (range: 3-95\%, AUC: 0.95). Collections sites in which the numbers of mosquitoes were higher than that expected within a Poisson distribution were then assumed to be population sources. Boqueirão Sul and Morro do São João (An. bellator), Sítio Itapuã (An. cruzii) and Boqueirão Norte (An. marajoara) (Table I) showed $\geq 80 \%$ potential habitat suitability for $\mathrm{An}$. bellator (Fig. 2A), An. cruzii (Fig. 2B) and An. marajoara (Fig. 2C). Abiotic and biotic values varied from $0-50^{\circ}$ (terrain slope), $1,400-2,792 \mathrm{~mm}$ (Bio12), $22.3-31.4^{\circ} \mathrm{C}$ (Bio5) and $0-100 \%$ (vegetation cover). The higher values were $13^{\circ}$ of terrain slope in Iporanga, $2,411 \mathrm{~mm}$ of Biol2 in Cananéia, $30.7^{\circ} \mathrm{C}$ of Bio5 in Registro and $94 \%$ of vegetation cover in Tapiraí. An. cruzii potential habitat suitability was positively correlated to terrain slope ( $\mathrm{rho}=$ $0.93, \mathrm{p}<0.001, \mathrm{df}=21$ ), high vegetation cover (e.g., $86 \%$ in Iporanga), low Biol2 (e.g., 1,602 mm in Iporanga) and Bio5 (e.g., $25.6^{\circ} \mathrm{C}$ in Juquitiba). An. bellator was posi-
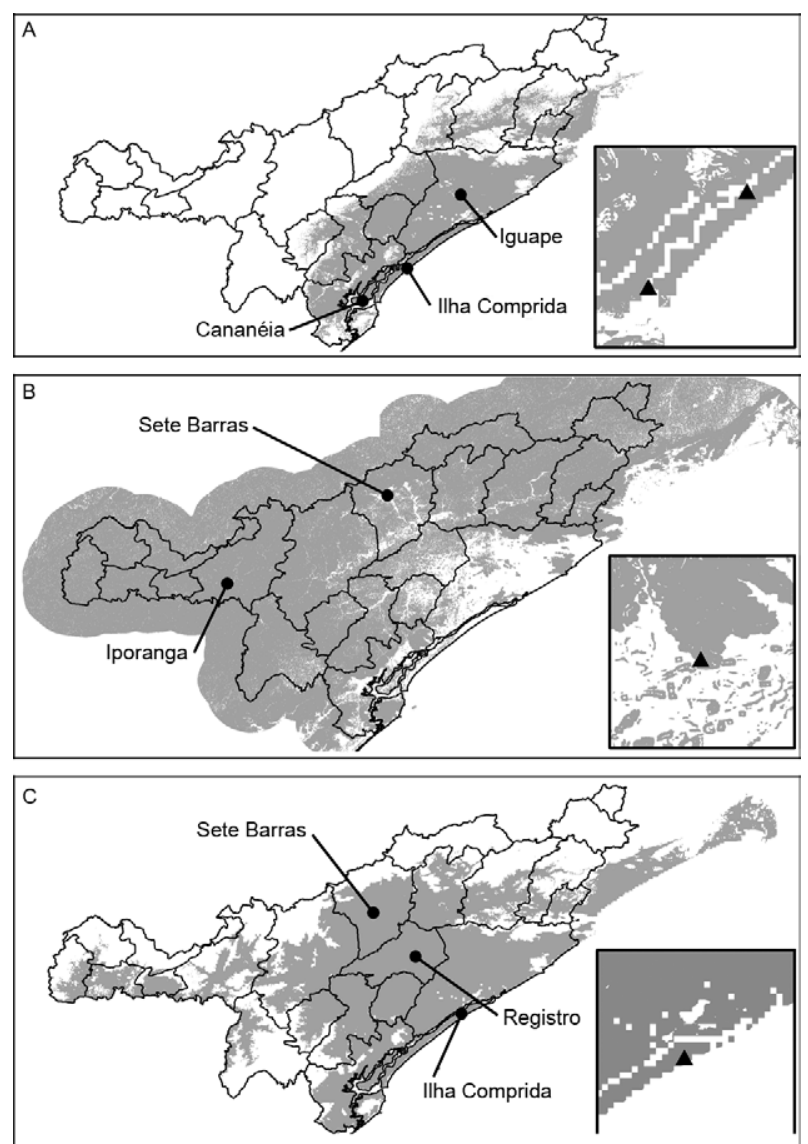

Control sites $\mathbf{\Delta}$

A: BoqSand CanSJ (Anopheles bellator)

B: CanT (Anopheles cruzil)

C: BoqN (Anopheles marajoara)

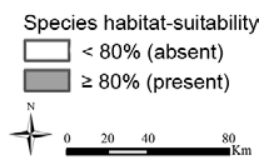

Fig. 2: binary potential habitat suitability maps (control sites have potential habitat suitability $\geq 80 \%$ ). A: Anopheles bellator [area under the receiver operating characteristic curve (AUC) 0.95, range 4-88\%]; B: Anopheles cruzii (AUC 0.91, range 51-97\%); C: Anopheles marajoara (AUC 0.95, range 3-95\%). tively correlated to Bio5 (rho $=0.62, \mathrm{p}<0.002, \mathrm{df}=21)$ and Biol2 (rho $=0.76, \mathrm{p}<0.001, \mathrm{df}=21)$ and negatively correlated to terrain slope (rho $=-0.43, \mathrm{p}<0.05, \mathrm{df}=21$ ). An. marajoara was positively correlated to Bio5 (rho $=$ $0.93, \mathrm{p}<0.001, \mathrm{df}=21)$ and negatively correlated to vegetation cover $(\mathrm{rho}=-0.35 ; \mathrm{p}<0.10, \mathrm{df}=21)$.

Malaria cases followed a Poisson distribution in which spatial autocorrelation was not significant (Mo$\operatorname{ran} \mathrm{Z}$ score $=1.71, \mathrm{p}<0.09$ ). The disease was distributed by municipalities with the following frequencies: one case each in Cananéia, Pariquera-Açu, Registro, Juquiá and Tapiraí, two cases each in Iguape and Pedro de Toledo, three in Miracatu and eight in Sete Barras (Supplementary data). Associations between malaria and dummy variables showed that models $1,4,5$ and 7, which include An. bellator as a vector, were not significant. On the other hand, models 3 (= malaria cases $\sim A n$. marajoara) and 6 (= malaria cases $\sim$ both An. cruzii and An. marajoara) were significant, showing associations between exposure to those mosquitoes and disease. The values obtained were $12.21(1.64-91.24, \mathrm{p}<0.02)$ and $4.36(1.46-13.05, \mathrm{p}<0.01)$, respectively (Table III).

\section{DISCUSSION}

Potential habitat suitability modelling revealed that the spatial distribution of An. cruzii is correlated with areas of ombrophilous dense forest that are present in the mountainous areas of the Vale do Ribeira (Fig. 2B), whereas An. bellator spatial distribution was determined by high Bio5 and Biol2 on the coastal low lands where the vegetation is the Atlantic Coast Restinga forest (Fig. $2 \mathrm{~A}$ ). Moreover, An. marajoara spatial distribution is correlated with high Bio5 and open areas of the Restinga or deforested lands associated with transformations of the natural ecosystem (Fig. 2C) (Forattini et al. 1995, Conn et al. 2002). Although differences among the values of

\section{TABLE III}

Poisson regression of malaria cases in function of binary potential habitat suitability $\geq 80 \%$ (presence) $/<80 \%$ (absence)

\begin{tabular}{|c|c|c|}
\hline $\begin{array}{l}\text { Models } \\
\text { (malaria cases } \sim \text { Poisson) }\end{array}$ & $\begin{array}{c}\mathrm{PR} \\
(95 \% \mathrm{CI})\end{array}$ & $\begin{array}{c}\mathrm{p} \\
\text { (Wald's test) }\end{array}$ \\
\hline $1:\left(\lambda=\mathrm{e}^{-0.31+0.43^{*} \mathrm{X} 1}\right)$ & $1.53(0.64-3.7)$ & $\mathrm{p}<0.35$ \\
\hline $2:\left(\lambda=\mathrm{e}^{-0.00-0.16 * \mathrm{X} 2}\right)$ & $0.85(0.25-2.9)$ & $\mathrm{p}<0.80$ \\
\hline 3: $\left(\lambda=\mathrm{e}^{-2.2+2.50^{*} \mathrm{X} 3}\right)^{a}$ & $12.21(1.64-91.24)$ & $\mathrm{p}<0.02$ \\
\hline $4:\left(\lambda=\mathrm{e}^{-0.25+0.43^{*} \mathrm{X} 4}\right)$ & $1.54(0.59-4.01)$ & $\mathrm{p}<0.39$ \\
\hline $5:\left(\lambda=\mathrm{e}^{-0.31+0.43 * \mathrm{X} 5}\right)$ & $1.53(0.64-3.7)$ & $\mathrm{p}<0.35$ \\
\hline $6:\left(\lambda=\mathrm{e}^{-1.01+1.47^{*} \mathrm{X} 6}\right)^{a}$ & $4.36(1.46-13.05)$ & $\mathrm{p}<0.01$ \\
\hline $7:\left(\lambda=\mathrm{e}^{-0.25+0.43 * \mathrm{X} 7}\right)$ & $1.54(0.59-4.01)$ & $\mathrm{p}<0.39$ \\
\hline
\end{tabular}

$a$ : significant model, prevalence ratio $(\mathrm{PR})>1$ and $(\mathrm{p}<0.05)$. Independent variables: $\mathrm{X}_{1}$ : Anopheles bellator; $\mathrm{X}_{2}$ : Anopheles cruzii; $\mathrm{X}_{3}$ : Anopheles marajoara; $\mathrm{X}_{4}$ : both An. bellator and An. cruzii; $\mathrm{X}_{5}$ : both An. bellator and An. marajoara; $\mathrm{X}_{6}$ : both An. cruzii and An. marajoara; $\mathrm{X}_{7}$ : An. bellator, An. cruzii and An. marajoara; CI: confidence interval. The results printed in bold represent significant outcomes under the null hypotheses $(\mathrm{PR}=1 ; \mathrm{p}<0.05)$. 
Bio5 and Bio12 were low, they were observed to be significant factors for distribution for An. bellator and An. marajoara (Table II). These findings may be related to the coarse 900 meter-spatial resolution of these variables for both the target mosquito population and study area. Also the significance of Bio5 and Bio12 may represent an indirect association with distribution of both species.

The AUC is not the best validation of potential habitat suitability maps when several niche factors of a species are poorly known. However, even considering the biases on the AUC related to the extrapolation of the data beyond a clustered sampled site (Lobo et al. 2008), the potential habitat suitability maps obtained are consistent with both ecological characteristics (Veloso 1958, Forattini et al. 1999, Marrelli et al. 2007) and registers of the presence of An. bellator, An. cruzii and An. marajoara (Forattini \& Massad 1998) in Vale do Ribeira. The potential habitat suitability maps were also validated by the probability values higher than $80 \%$ for species control sites (Fig. 2, Table I).

Results of the present study were to associate mosquito potential distribution with malaria cases; these results are of further interest because they show that the spatial distribution of An. cruzii and An. bellator do not overlap at a larger geographical scale. An. cruzii is present on the hills, whereas An. bellator is present along the coastal shore of Vale do Ribeira. This lack of range overlap could be the result of either chance distribution or the competitive exclusion described by Gause (1934) because several unknown ecologic niche dimensions determine their actual distribution. Additionally, the potential habitat suitability for An. marajoara indicates that this species has a broader potential spatial distribution than that hypothesized by Wilkerson et al. (1995) in the Vale do Ribeira. As a result, further studies will be necessary to validate the prediction distribution models generated herein. Finally, it would be important to sample mosquitoes in areas with a high probability of the presence of the species that have never been sampled.

Results of the Poisson regression suggest that the presence of An. bellator is not significantly associated with malaria (Table III). In contrast, this disease is significantly associated with An. marajoara and the presence of both An. marajoara and An. cruzii (Table III). These results are partially in accordance with the hypothesis of Curado et al. (2006) and Duarte et al. (2008), which suggest that in areas of the Atlantic Forest, humans can become infected with human Plasmodium when they invade the natural foci of An. cruzii and the Alouatta spp of monkeys, which serve as the reservoirs of Plasmodium sp. Moreover, Curado et al. (2006) performed enzyme immunosorbent assay tests and found a prevalence of antibodies against $P$. vivax in $63(35 \%)$ and 155 (29.7\%) humans from Parque Estadual Intervales and Parque Estadual do Alto do Ribeira, respectively. Interestingly, Curado et al. (2006) showed that the majority of the captured mosquitoes were An. cruzii in both areas, which are in the municipality of Iporanga. The spatial distribution modelling analyses indicated that the potential habitat suitability for this species was $95 \%$ in this municipality. On the other hand, the large and sig- nificant association between An. marajoara spatial distributions with cases of malaria was not in accordance with the hypothesis of Curado et al. (2006) and Duarte et al. (2008). This contradictory result might have occurred because these authors had not done their research in the municipality of Sete Barras, which had $40 \%$ of all autochthonous malaria cases occurring in Vale do Ribeira between 1996-2000 (Supplementary data). This underscores the need to sample mosquito assemblages from this municipality.

In considering the results obtained in the present study and the association between malaria cases and the potential spatial distribution of An. marajoara, we hypothesize that An. marajoara seems to be involved in the dynamics of malarial transmission in areas of the Vale do Ribeira. Cohuet et al. (2010) hypothesized that Plasmodium exerts selective pressure on its vectors in order to increase its own dissemination - shaping the vector to its own benefit. In this sense, it is probable that Plasmodium species is circulating in the Vale do Ribeira by keeping a sylvatic cycle that involves Anopheles (Kerteszia) mosquitoes and Alouatta monkeys as reservoirs and occasionally humans, as well as a cycle that involves humans and mosquito species of the subgenus Nyssorhynchus (e.g., An. marajoara). This species was demonstrated to be a competent vector in Vale do Ribeira in the 1940s (Schiavi 1945). Furthermore, Conn et al. (2002) showed that $A n$. marajoara from Macapá became the primary vector of Plasmodium because of the increasing habitation of this species in non-forested and marshy lands used for agriculture, combined with the intensive human migration of infected individuals from other locations in the Amazon where transmissions were endemic.

In Vale do Ribeira, deforestation and changes in the land use may have affected the dynamics of malarial transmission, leading to a local succession of vector species of the subgenus Kerteszia and of the subgenus Nyssorhynchus (e.g., An. marajoara). In addition, adult populations of An. albitarsis l.s. are abundant and dominant in irrigated rice fields (Forattini et al. 1995), showing that these human-modified environments can create ecological conditions that favour species of the Nyssorhynchus subgenus that are vectors of Plasmodium.

As landscape structure is an important determinant for the dynamics of infectious diseases, man-made modifications can create ecological and microclimate conditions that favour some mosquito vector species and also the pathogens they transmit (Castro et al. 2006, Olson et al. 2010). Vittor et al. (2006) showed that deforestation increased the rate of contact between An. darlingi and humans in the Peruvian Amazon, thereby increasing the incidence of malaria in the region. Similarly, Castro et al. (2006) demonstrated that the early stages of frontier settlement are dominated by environmental risks of malarial transmission. Olson et al. (2010) showed that $4.3 \%$ of changes in the natural environment caused by deforestation were associated with a $48 \%$ increase in malarial incidence in the municipality of Mâncio Lima, state of Acre. Similarly, in the Vale do Ribeira, ecological conditions that favour the presence of habitats for $A n$. marajoara, combined with the migration of individuals 
infected with human Plasmodium, might change the current status of low and dispersed malarial transmission in that region. The results of the present study suggest that malarial transmission will continue and may become exacerbated if the proportion of natural forest remnants is reduced in the Atlantic Forest.

\section{ACKNOWLEDGEMENTS}

To Henry Rupp, for kindly reviewing the English, and the three anonymous reviewers, for comments and suggestions that greatly improved the first draft of the paper.

\section{REFERENCES}

Ayala D, Costantini C, Ose K, Kamdem GC, Antonio-Nkondjio C, Agbor JP, Awono-Ambene P, Fontenille D, Simard F 2009. Habitat suitability and ecological niche profile of major malaria vectors in Cameroon. Malaria J 8: 307.

Boscolo D, Metzger JP 2009. Is bird incidence in Atlantic Forest fragments influenced by landscape patterns at multiple scales? Lands Ecol 24: 907-918.

Castro MC, Monte-Mór RL, Sawyer DO, Singer BH 2006. Malaria risk on the Amazon frontier. Proc Nat Acad Sci 103: 7.

Cohuet A, Harris C, Robert V, Fontenille D 2010. Evolutionary forces on Anopheles: what makes a malaria vector? Trends Parasitol 26: $130-136$.

Conn JE, Wilkerson RC, Segura MNO, Souza RTL, Schlichting CD, Wirtz RA, Póvoa MM 2002. Emergence of a new malaria vector facilitated by human migration and changes in land use. $\mathrm{Am} \mathrm{J}$ Trop Med Hyg 66: 18-22.

Correa RR, Lima FO, Coda D 1950. Observations on the flight and longevity in nature of Anopheles albitarsis domesticus. J Natl Malar Soc 9: 280-284.

Couto RD, Latorre MRDO, Di Santi SM, Natal D 2010. Autochthonous malaria notified in the state of São Paulo: clinical and epidemiological characteristics from 1980 to 2007. Rev Soc Bras Med Trop 43: 52-58.

Curado I, Malafronte RS, Duarte AMRC, Kirchgatter K, Branquinho MS, Galati EAB 2006. Malaria epidemiology in low-endemicity areas of the Atlantic Forest in the Vale do Ribeira, São Paulo, Brazil. Acta Trop 100: 54-62.

Duarte AMRC, Malafronte RS, Cerutti C Jr, Curado I, Paiva BR, Maeda AY, Yamasaki T, Summaf MEL, Neves DVDA, Oliveira SG, Gomes AC 2008. Natural Plasmodium infections in Brazilian wild monkeys: reservoirs for human infections? Acta Trop 107: 179-185.

Fielding AH, Bell JF 1997. A review of methods for the assessment of prediction errors in conservation presence/absence models. Environ Conserv 24: 38-49.

Forattini OP, Kakitani I, Massad E, Marucci D 1995. Studies on mosquitoes (Diptera: Culicidae) and anthropic environment. 7 - Behaviour of adults Nyssorhynchus anophelines with special reference to Anopheles albitarsis s.l. in south-eastern Brazil. Rev Saude Publica 29: 20-26.

Forattini OP, Kakitani I, Santos RL, Ueno HM, Kobayashi KM 1999. Role of Anopheles (Kerteszia) bellator as malaria vector in southeastern Brazil (Diptera: Culicidae). Mem Inst Oswaldo Cruz 94: 715-718.

Forattini OP, Massad E 1998. Culicidae vectors and anthropic changes in a southern natural ecosystem. Ecosys Hlth 4: 9-19.

Gause GF 1934. The struggle of existence, Williams \& Wilkins, Baltimore, $176 \mathrm{pp}$.

Hanski I 1994. A practical model of metapopulation dynamics. J Anim Ecol 63: 151-162.
Hay SI, Sinka ME, Okara RM, Kabaria CW, Mbithi PM, Tago CC, Benz D, Gething PW, Howes RE, Patil AP, Temperley WH, Bangs MJ, Chareonviriyaphap T, Elyazar IRF, Harbach RE, Hemingway J, Manguin S, Mbogo CM, Rubio-Palis Y, Godfray HCJ 2010. Developing global maps of the dominant Anopheles vectors of human malaria. PLoS Med 7: e1000209.

Kronka FJN, Nalon MA, Matsukuma CK 2005. Inventário florestal da vegetação natural do estado de São Paulo, Instituto Florestal da Secretaria do Meio Ambiente, São Paulo, 200 pp.

Lobo JM, Jiménez-Valverde A, Real R 2008. AUC: a misleading measure of the performance of predictive distribution models. Global Ecol Biogeogr 17: 145-151.

Lyra-Jorge MC, Ribeiro MC, Ciocheti G, Tambosi LR, Pivello VR 2010. Influence of multi-scale landscape structure on the occurrence of carnivorous mammals in a human-modified savanna, Brazil. Eur J Wildl Res 56: 359-368.

Marrelli MT, Malafronte RS, Sallum MAM, Natal D 2007. Kerteszia subgenus associated with the Brazilian Atlantic forest: current knowledge and future challenges. Malar J 6: 127.

Metz CE 1986. ROC methodology in radiologic imaging. Invest Radiol 21: 720-733.

Motoki MT, Wilkerson RC, Sallum MAM 2009. The Anopheles albitarsis complex with the recognition of Anopheles oryzalimnetes Wilkerson and Motoki, n. sp. and Anopheles janconnae Wilkerson and Sallum, n. sp. (Diptera: Culicidae). Mem Inst Oswaldo Cruz 104: 823-850.

Oliveira-Ferreira J, Lacerda MVG, Brasil P, Ladislau JLB, Tauil PL, Daniel-Ribeiro CT 2010. Malaria in Brazil: an overview. Malal J 9: 115.

Olson SH, Gangnon R, Silveira G, Patz JA 2010. Deforestation and malaria in Mâncio Lima County, Brazil. Emerg Infect Dis 16: 1108-1115.

Phillips SJ, Anderson RP, Schapire RE 2006. Maximum entropy modeling of species geographic distributions. Ecol Modell 190: 231-259.

Ribeiro MC, Metzger JP, Martensen AC, Ponzoni FJ, Hirota MM 2009. The Brazilian Atlantic Forest: how much is left and how is the remaining forest distributed? Implications for conservation. Biol Conserv 142: 1141-1153.

Roque F, Siqueira T, Bini LM, Ribeiro MC, Tambosi LR, Ciocheti G, Trivinho-Strixino S 2010. Untangling associations between chironomid taxa in Neotropical streams using local and landscape filters. Freshw Biol 55: 847-865.

Schiavi A 1945. Nota sobre mosquitos vetores em Iguape. Arq Hig Saude Publica 10: 69-75.

Sinka ME, Rubio-Palis Y, Manguin S, Patil AP, Temperley WH, Gething PW, Boeckel TV, Kabaria CW, Harbach RE, Hay SI 2010. The dominant Anopheles vectors of human malaria in the Americas: occurrence data, distribution maps and bionomic précis. Parasit Vectors 3: 72.

Soberón J 2007. Grinnellian and Eltonian niches and geographic distributions of species. Ecol Lett 10: 1115-1123.

Veloso HP 1958. O relêvo do solo como fator determinante da distribuição dos anofelíneos na região "Bromeliácea-Malária" do Brasil. Mem Inst Oswaldo Cruz 56: 25-33.

Vittor AY, Gilman RH, Tielsch J, Glass G, Shields T, Lozano WS, Pinedo-Cancino V, Patz JA 2006. The effect of deforestation on the human-biting rate of Anopheles darlingi, the primary vector of Falciparum malaria in the Peruvian Amazon. Am J Trop Med Hyg 74: 3-11.

Wilkerson RC, Gaffigan TV, Lima JB 1995. Identification of species related to Anopheles (Nyssorhynchus) albitarsis by random amplified polymorphic DNA-polymerase chain reaction (Diptera: Culicidae). Mem Inst Oswaldo Cruz 90: 721-732. 


\section{TABLE}

The mean and standard deviations of the number of mosquitoes monthly collected per species and collection site in the south-eastern Atlantic Forest of Brazil

\begin{tabular}{lccc}
\hline Sites & $\begin{array}{c}\text { Anopheles } \\
\text { bellator }\end{array}$ & $\begin{array}{c}\text { Anopheles } \\
\text { cruzii }\end{array}$ & $\begin{array}{c}\text { Anopheles } \\
\text { marajoara }\end{array}$ \\
\hline BoqN & $1.50 \pm 1.62$ & $16.17 \pm 5.25$ & $10.50 \pm 4.17$ \\
BoqS & $149.67 \pm 17.08$ & $42.42 \pm 11.24$ & $1.75 \pm 1.55$ \\
CanSJ & $43.58 \pm 8.03$ & $37.83 \pm 10.18$ & $0.33 \pm 0.49$ \\
CanT & $26.34 \pm 7.20$ & $229.25 \pm 19.24$ & $0.00 \pm 0.00$ \\
FazE & $0.00 \pm 0.00$ & $29.33 \pm 9.86$ & $0.75 \pm 0.75$ \\
S_Ga & $0.92 \pm 1.17$ & $50.92 \pm 9.62$ & $0.00 \pm 0.00$ \\
Ica_I & $3.00 \pm 2.26$ & $45.25 \pm 10.53$ & $0.00 \pm 0.00$ \\
Par & $0.00 \pm 0.00$ & $1.17 \pm 1.47$ & $0.00 \pm 0.00$ \\
V_M & $0.00 \pm 0.00$ & $0.00 \pm 0.00$ & $0.00 \pm 0.00$ \\
\hline
\end{tabular}

mosquito collection sites: BoqN: Ilha Comprida (North); BoqS: Ilha Comprida (South); CanSJ: Cananéia; CanT: Sítio Itapuã; FazE: Fazenda Experimental; S_Ga: Sítio Galiléia; Ica_I: Icapara; Par: Pariquera-Mirim; V_M: Vila Maria.
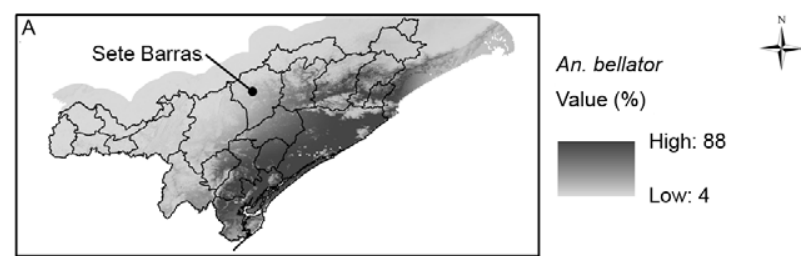

Value (\%)
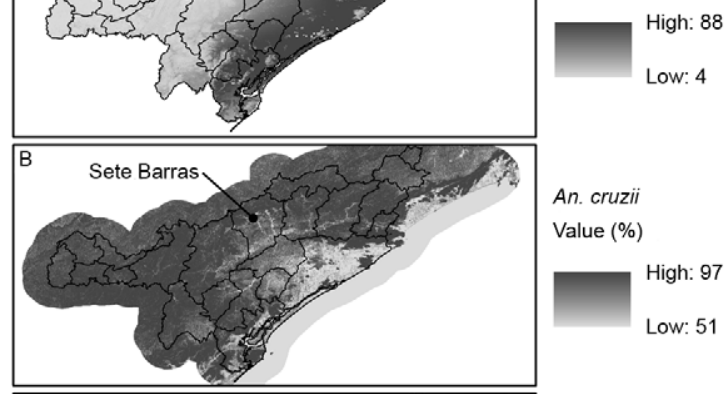

An. cruzii

Value (\%)
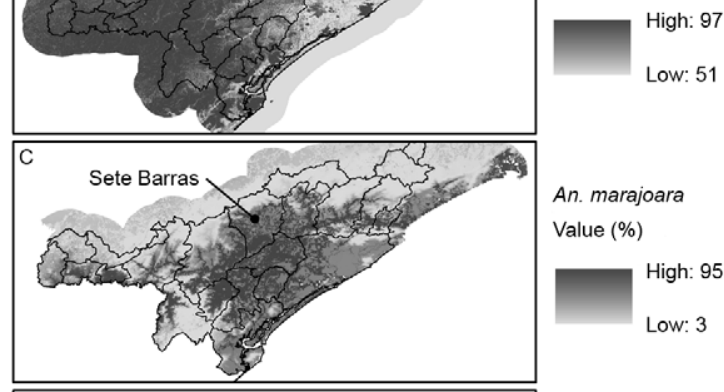

An. marajoara

Value (\%)
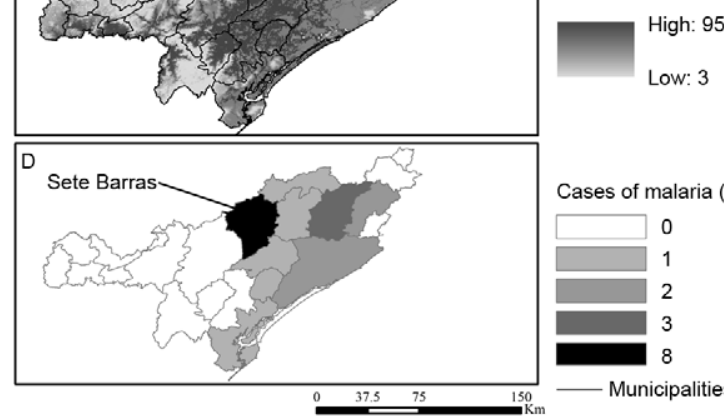

Cases of malaria $(n)$

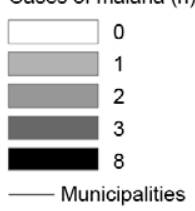

Anopheles bellator (A), Anopheles cruzii (B), Anopheles marajoara (C) potential habitat suitability maps, and cases of malaria (D) in the southeastern Atlantic Forest of Brazil. Potential habitat suitability of An. cruzii is beyond the slopes of Serra do Mar. 